Article

\title{
Determination of the Support Level of Local Organizations in a Model Forest Initiative: Do Local Stakeholders Have Willingness to Be Involved in the Model Forest Development?
}

\author{
Ahmet Tolunay ${ }^{1, *}$, Türkay Türkoglu ${ }^{2}$, Marine Elbakidze ${ }^{3}$ and Per Angelstam ${ }^{3}$ \\ 1 Faculty of Forestry, Suleyman Demirel University, Isparta 32000, Turkey \\ 2 Department of Forestry, Koycegiz Vocational School, Mugla Sitki Kocman University, \\ Mugla 48800, Turkey; E-Mail: turkayturkoglu@mu.edu.tr \\ 3 Faculty of Forest Sciences, School for Forest Management, Swedish University of Agricultural \\ Sciences, Uppsala PO Box 43 73921, Sweden; E-Mails: marine.elbakidze@slu.se (M.E.); \\ per.angelstam@slu.se(P.A.) \\ * Author to whom correspondence should be addressed; E-Mail: ahmettolunay@sdu.edu.tr; \\ Tel.: +90-246-211-3952; Fax: +90-246-237-1810.
}

External Editor: Marc A. Rosen

Received: 13 July 2014; in revised form: 7 October 2014 / Accepted: 9 October 2014 / Published: 17 October 2014

\begin{abstract}
Voluntary cooperation and the support of stakeholders carry a major importance in the development of Model Forests. The identification of the support level of local organizations as stakeholders in the Bucak Model Forest initiative, located in the Mediterranean region of Turkey, constitutes the theme of this study. Within this scope, the views of the stakeholders comprising local government units (LGUs), non-governmental organizations (NGOs), village councils (VCs), professional organizations (POs) and forest products enterprises (FPEs) located in the district of Bucak were collected by utilizing a survey technique. The data were analysed by using non-parametric statistical analyses due to the absence of a normal distribution. The results show that the information provided about the Model Forest concept to the stakeholders located in the district on the Bucak Model Forest initiative was identified as a factor impacting the support level. Moreover, it was also observed that the stakeholders were more willing to provide advisory support rather than financial support. NGOs and VCs were identified as stakeholders who could not provide financial support due to their restricted budgets. We discuss the benefits for a
\end{abstract}


Model Forest initiative of establishing international cooperation to strengthen the local and regional sustainable development process.

Keywords: local organizations; stakeholders; model forest concept; willingness to support; multi-level learning; Bucak model forest initiative; Mediterranean region; Turkey

\section{Introduction}

Sustainable forest management (SFM) is a concept in transition from a focus on sustained yield of wood to products from multiple goods, services and values of forest landscapes $[1,2]$. SFM has become the dominant paradigm for forest management and conservation in the world [3-5]. Since the early 1990s, the international forest policy discourse recommends that economic, ecological and social values should be taken into account [6-10]. SFM is a concept under continuous development, the interpretation of which varies over time, among countries, regions and even local landscapes [2,11]. SFM is supported by different international processes and organizations, taking into account the specific forest condition in different parts of the world [12-14]. Pan-European criteria and indicators for SFM have been developed by the Ministerial Conferences on Protection of Forest in Europe (MCPFE) (e.g., MCPFE, 1993, 1995, 1998a, 2001) [15] and by the Working Group on Criteria and Indicators for the Conservation and Sustainable Management of Temperate and Boreal Forests [14]. The identified criteria and indicators for SFM can be used to measure and track the status of the world's forests at the national level, or in some cases, at the forest management unit level [4].

Realising ambitions of SFM as a process requires that actors and stakeholders of forest landscapes collaborate at multiple levels. Thus, a crucial condition for implementation of SFM on the ground is public participation [16]. Participatory management of natural resources has become a widely accepted management philosophy, particularly for community-managed resources [17]. Successful community-based forest management entails effective collaborative decision-making, which in turn depends on understanding and communication [5,18]. To support sustainable development in forest landscapes by implementing SFM policy, different international and national concepts and initiatives have been developed such as Biosphere Reserves, Leader Plus, the Polish Promotional Forest Complexes [19,20]. Explicitly or implicitly, all these approaches acknowledge the complexity of ecosystems and social systems, and seek to address the challenges of accommodating multiple users' claims and interests.

Model Forest is one of such concepts. This concept was developed and initiated by the Canadian Forest Service in 1991 [21]. Canada's Prime Minister announced the Model Forest concept globally at the United Nations Conference on Environment and Development (UNCED) in 1992. He invited other countries to join in testing this innovative approach towards SFM that appeared to be promising in Canada [22]. The International Model Forest Network (IMFN) was acknowledged globally at the UNCED in 1992 [23]. The key functions of a Model Forest concept are to test new ideas and develop innovations related to sustainable development, as agreed by Model Forest's partners, with the goal of developing the adaptive capacity of the local social-ecological system to deal with uncertainty and change $[24,25]$. The development of collective action as a base for SFM implementation on the ground differs among places as well as over time. It can be initiated by local stakeholders bottom-up, or 
facilitated by external actors top-down. Different stakeholders may also have different interests and needs for taking part in collective action [25].

The IMFN has encouraged the establishment of a multi-level network of collaborative partnerships [21]. Elbakidze et al. explained the importance of collaboration between multi-stakeholders for local and regional Model Forest initiatives [25]. Sinclair and Smith also emphasized that stakeholders participating in the IMFN work together to achieve consensus on SFM [26]. Chouinard and Perron presented community capacity-building learning via the Model Forest experience [27]. As in Kovdozersky Model Forest in Russia [28], many forest administrations want to participate in the Model Forest program because it provides innovative approaches to regional sustainable development. The IMFN currently comprises six regional networks or regions. These are Africa, Asia, Northern Europe and Russia, Canada, Ibero-America and Mediterranean. In total, these sites cover over 108 million hectares of land, reflecting a variety of land ownerships, including state or private ownership, large industrial forests, unprotected public land and protected areas in different countries [29].

According to the Model Forest development guide [30], the Model Forest concept has six key principles. These are: (1) a landscape large enough to address an area's diverse forest uses and values; (2) an inclusive and representative partnership; (3) a commitment to sustainability; (4) a governance system that is representative, transparent, and accountable; (5) a program of activities that reflects the values, needs, and management challenges of the partners, in the local community, and on regional to national levels; and (6) a commitment to knowledge sharing, capacity building, and networking, from local to international levels [31]. Two principles are of a more basic character ( 1 and 3) whereas principles 2 and 4-6 can be considered as principles of a multi-stakeholder collaboration approach [25]. It is highly important to achieve voluntary cooperation and receive the support of stakeholders in the development process of a Model Forest where natural resource management partnerships are established, without endangering the heritage to be transferred to future generations. Thus, a Model Forest is a large-scale, forest-based landscape that encompasses a variety of land uses and values, resource management administrations and land ownership. The terms landscape, sustainability and partnership are central [30].

The key functions of a Model Forest are to develop innovations and test new ideas related to SFM, driven by the needs, interests and problems of Model Forests' partners [25,30]. Thus, it is necessary to identify and analyse different stakeholders' preferences in terms of activities that would maintain or support goods, values and services of forest landscapes important for different groups of stakeholders. Results from such analyses should be reflected in the strategy and program of Model Forest's activities in order to enhance its adaptive capacity [28].

In Turkey, Model Forest development was initiated by the governmental organization General Directorate of Forestry (GDF) in 2009. The Yalova Model Forest became the first such initiative in the country, and it was accepted as a candidate by the IMFN in 2010 and became a member in 2011. Due to its location, the Yalova Model Forest is included into the Mediterranean Model Forest Network [31]. Recently, the second Model Forest in Turkey, in the Bucak administrative district, was initiated. This region was selected by the GDF due to its location and its special attributes.

In Turkey, 99 per cent of the forests belong to the state. The forests are managed by the GDF [3]. Turkey has decided to manage its forest resources within the framework of international agreements according to the principles of SFM [32,33]. The National Forestry Program of Turkey (2004) focuses on developing participation in the management of forest resources, ensuring transparency in decisions 
related to forestry, informing the society about all processes and decisions related to forest resource uses and developing strategies and programs aimed at reducing poverty in forest villages and providing rural development [34].

International collaboration is important for learning and exchanging experiences among involved stakeholders, and should be encouraged in order to implement SFM on the ground. Model Forest is one a concept providing a joint perspective at a global scale in terms of contributing to sustainable development. With one Model Forest as a member of the IMFN and Bucak as the second in the process of joining it, Turkey will be able to present to the world the experiences gained in SFM applications and also receive international support for the solution of some problems. From this respect, membership in the IMFN carries a major importance for Turkey.

A Model Forest is a process in which the people and organizations build partnerships for the management of forest resources and values in a landscape. Therefore, the stakeholders of Model Forests represent public and private entities and non-governmental organizations (NGOs) at multiple levels of governance.

The aim of this study is to analyse how different stakeholders accept the Model Forest concept in Turkey, using one emerging Model Forest initiative, the Bucak Model Forest (BMF), as a case study. Do local stakeholders have willingness to be involved in the BMF development? If so, what activities are most important for stakeholders representing different societal sectors? Addressing these questions enabled us to measure local willingness of being involved in the development of a regional Model Forest initiative and to better understand opportunities and challenges associated with implementation of Model Forest initiatives on the ground. We discuss how multi-level social learning could contribute to better understanding of the Model Forest concept by different stakeholders.

\section{Methodology}

\subsection{Study Area}

The Bucak Model Forest (BMF) initiative $\left(37^{\circ} 27^{\prime} \mathrm{N}\right.$ and $\left.30^{\circ} 35^{\prime} \mathrm{E}\right)$ is located in the Bucak district in the Burdur province in SW Turkey (Figure 1). The Taurus Mountains with deep river valleys is characteristic for Bucak's landscapes. The average altitude of Bucak district is 1000 meters. Approximately $70 \%$ of the Bucak district is covered with forests and woodlands (97,881 ha). The main tree species are Lebanon cedar (Cedrus libani A. Rich), Calabrian pine (Pinus brutia Ten.) and umbrella pine (Pinus pinea L.). All forests are owned by the state, and the Directorate of the Bucak Forestry Enterprise manages the forests following the national forestry objectives. The coniferous forests are mainly used for wood production. The Bucak forest enterprise provides many jobs for local people. Forests are also important for local communities as a living place and a source of non-wood forest products (NWFPs) (gale branch-apiculture, mushrooms, medicinal and aromatic plants, laurel-wreath production, and ornamental horticulture). The collection of NWFPs has increased during recent years. Forests play also an important role for recreation and eco-tourism on regional, national, and international levels. The district has a population of 64,188 people [35]. There are 34 forest villages, six towns, and one district center. 
Figure 1. Location of the Bucak region's Model Forest in the eastern part Burdur province in Turkey.

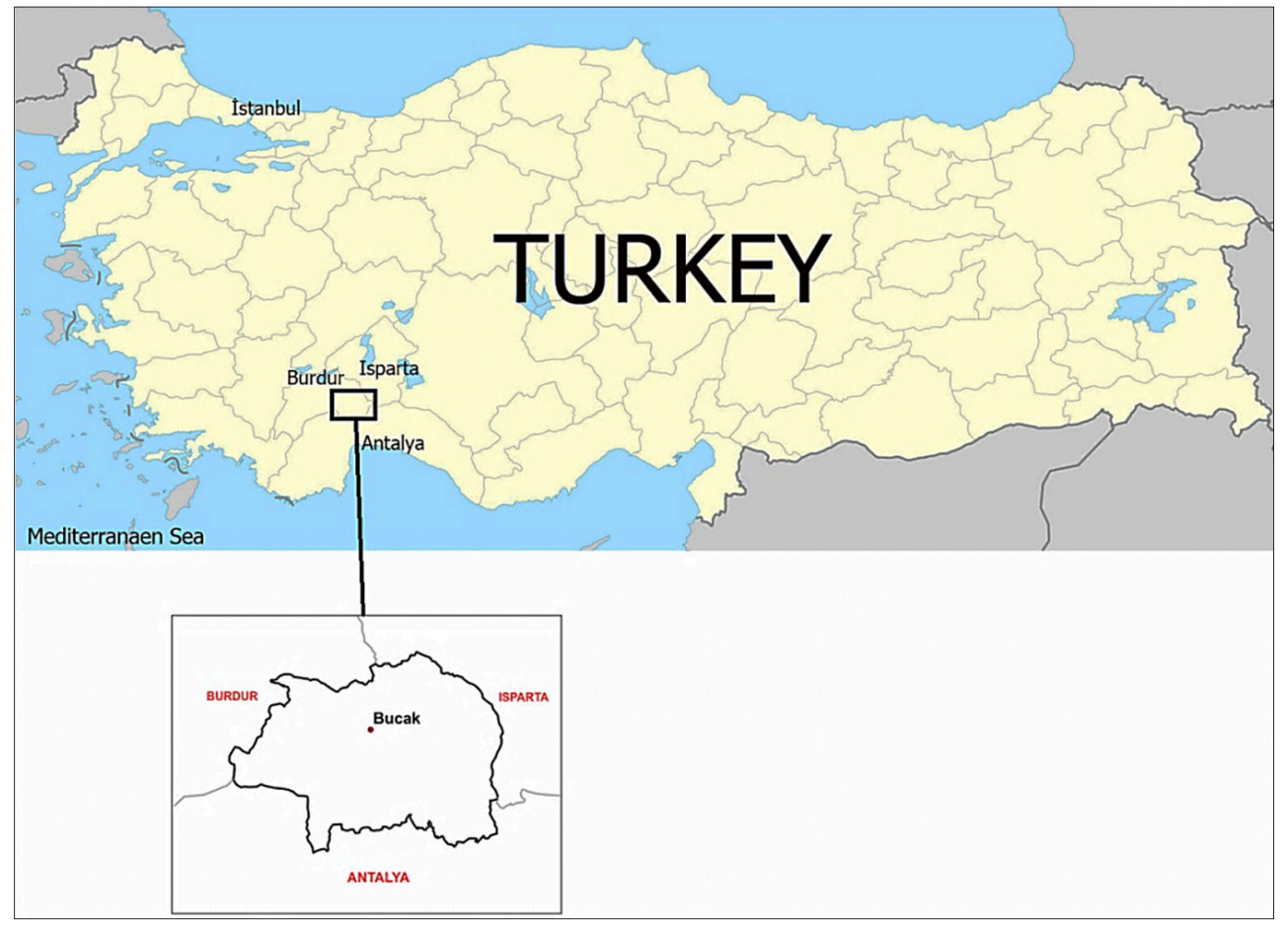

\subsection{Identification of Stakeholder Groups}

During the establishment of the BMF, the Bucak state forest administration held meetings with local people and local organizations in order to explain the purpose of the Model Forest concept, and thus to gain local support for the development of BMF. To investigate the level of support provided by local stakeholders to the BMF initiative, we selected stakeholders that operated in the Bucak landscape for in-depth study. The stakeholders represented public, NGOs, local administrations and the private sector in the region. Stakeholders included both those who were and who were not informed about the mission of the BMF by the Bucak state forest administration. The purpose of this study design was to understand if the level of support of Model Forest development by local stakeholders depended on their level of knowledge about the Model Forest concept in general, and the BMF in particular. All stakeholders were grouped according to the sector that they represented [25], i.e., (i) the civil sector, comprising a broad range of organizations outside of government, including civil associations, non-profit organizations, churches, and neighbourhood clubs that contribute to the public good [36]; (ii) the private sector, made up of businesses controlled or owned by private individuals, directly or through stock ownership; and (iii) the public sector, which is formed by stakeholders representing public interests through governmental agencies and local government units (LGUs).

In total, we identified 144 stakeholders in the area of BMF. These included 60 from the civil sector (NGOs and professional organizations (POs), including professional chambers and cooperatives), 20 forest products enterprises (FPE) from the private sector, and 64 stakeholders (34 village councils (VCs) and 30 LGUs) from the public sector. Although the aim was to reach all stakeholders, only 80 organizations participated in the study because some did not want to express their views, and others could not be reached (Table 1, Figure 2). The groups of stakeholder with the highest participation rate in the survey were POs (88\%) and LGUs (77\%). The other stakeholder groups' participation rates were under 50\%. 
Table 1. Stakeholder groups representing different sectors in the Bucak Model Forest area.

\begin{tabular}{|c|c|c|c|c|c|}
\hline \multirow{2}{*}{ Sectors } & \multirow{2}{*}{$\begin{array}{l}\text { Stakeholder } \\
\text { Groups }\end{array}$} & \multirow{2}{*}{ Definition } & \multicolumn{2}{|c|}{ Stakeholders } & \multirow{2}{*}{$\begin{array}{c}\begin{array}{c}\text { Rate of } \\
\text { survey } \\
\text { conducted }\end{array} \\
(\%)\end{array}$} \\
\hline & & & Population & Sample size & \\
\hline \multirow[t]{2}{*}{$\begin{array}{l}\text { Civil } \\
\text { sector }\end{array}$} & $\begin{array}{l}\text { Non-Governmental } \\
\text { Organizations } \\
\text { (NGOs) }\end{array}$ & $\begin{array}{l}\text { Non-profit associations, } \\
\text { environmental organizations, peoples } \\
\text { organizations, registered societies } \\
\text { and other associations in Bucak }\end{array}$ & 44 & 17 & 40 \\
\hline & $\begin{array}{l}\text { Professional } \\
\text { Organizations (POs) }\end{array}$ & $\begin{array}{l}\text { Professional associations in Bucak } \\
\text { and cooperative enterprises }\end{array}$ & 16 & 14 & 88 \\
\hline $\begin{array}{l}\text { Private } \\
\text { sector }\end{array}$ & $\begin{array}{l}\text { Forest Product } \\
\text { Enterprises (FPEs) }\end{array}$ & $\begin{array}{l}\text { Timber and non-wood forest } \\
\text { products enterprises }\end{array}$ & 20 & 9 & 45 \\
\hline \multirow[t]{2}{*}{$\begin{array}{l}\text { Public } \\
\text { sector }\end{array}$} & $\begin{array}{l}\text { Local Government } \\
\text { Units (LGUs) }\end{array}$ & $\begin{array}{l}\text { Governorship of Bucak, } \\
\text { Municipality of Bucak and } \\
\text { Municipalities of other towns, } \\
\text { Forestry Administration of Bucak, } \\
\text { Directorate of Food, Agriculture } \\
\text { and Livestock, Land Office, } \\
\text { County Constabulary, National } \\
\text { Estate, Directorate of Bucak } \\
\text { National Education, Regional } \\
\text { Healthcare Center, Vocational } \\
\text { School of Bucak (M. Akif Ersoy } \\
\text { University) and other governmental } \\
\text { offices in Bucak }\end{array}$ & 30 & 23 & 77 \\
\hline & $\begin{array}{l}\text { Village councils } \\
\text { (VCs) }\end{array}$ & $\begin{array}{l}\text { VCs in Bucak (groups composed of } \\
\text { headmen and members) }\end{array}$ & 34 & 17 & 50 \\
\hline TOTAL & & & 144 & 80 & \\
\hline
\end{tabular}

Figure 2. The proportion of local stakeholders $(n=80)$ representing civil, private and public sectors and operating in the area of Bucak Model Forest that were included in the study.

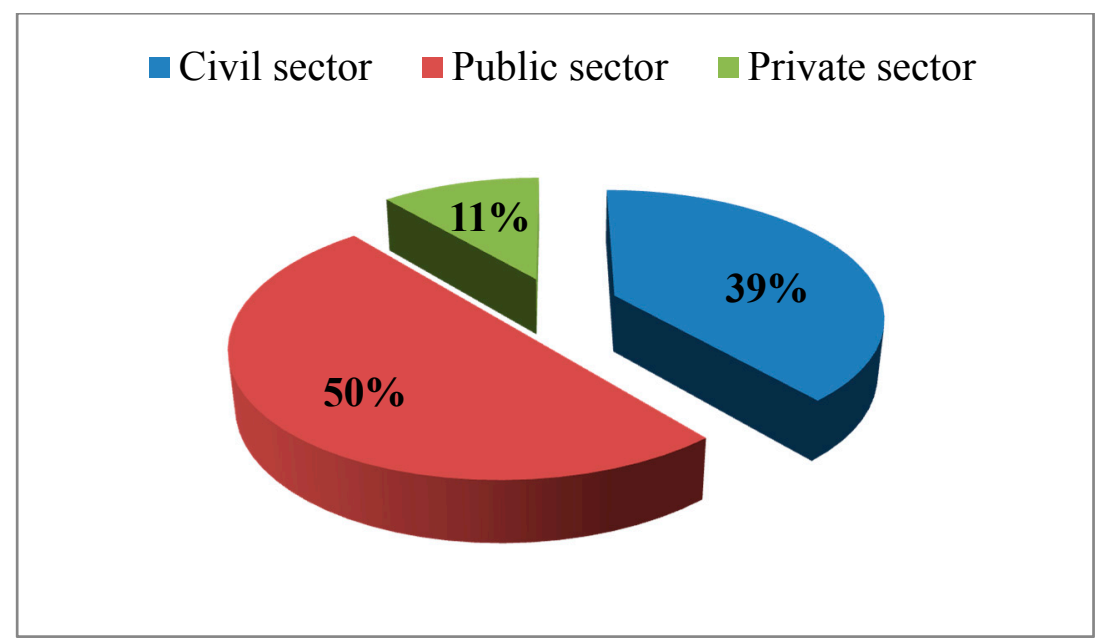




\subsection{Survey Design and Statistical Analyses of Stakeholders' Willingness and Preferences}

To identify stakeholders' support level for the BMF initiative a questionnaire was conducted with 80 local stakeholders in January-March, 2014. The questionnaire contained 16 questions that were divided into two groups. The first group contained questions on the willingness to be involved in the activities of the BMF, to provide an advisory support for economic development, and/or to provide financial support. The stakeholders were asked to answer "yes" or "no". The questions in the second group were about activities of the BMF that stakeholders might be willing to participate in or to support. Here, the answer alternatives were strongly agree $=5$, agree $=4$, undecided $=3$, disagree $=2$, and strongly disagree $=1$.

The statistical analyses were done using SPSS 20 Statistics Package Program. The Cronbach's Alpha coefficient was calculated at 0.874 . The distribution of the data was checked in order to see the type and accumulation points of the data. In order to serve this purpose, the Kolmogrov-Smirnov Test was preferred due to the collection of data from 80 stakeholders in the study with regard to the distribution of data; the $\mathrm{H}_{0}$ (Null) hypothesis was formulated as "the distribution of data is in line with the normal distribution", while the $\mathrm{H}_{\mathrm{a}}$ (Alternative) hypothesis was formulated as "the distribution of data is not in line with the normal distribution".

The $\mathrm{H}_{0}$ hypothesis was rejected as the Asmp. Sig. (2-tailed) values obtained through the Kolmogrov-Smirnov Test conducted with a significance level of 5\% were less than $5 \%$ (between min. 0.00 and max. 0.02). As the data did not have a normal distribution, non-parametric tests were preferred. First of all, as the support of stakeholders changed also according to being or not being informed about the Model Forest, the Mann-Whitney U test was conducted among the non-parametric Independent Samples T-test. Within this scope, the $\mathrm{H}_{0}$ hypothesis was formulated as "there is no difference between the support level by stakeholders that are informed about the BMF", while the $\mathrm{H}_{\mathrm{A}}$ hypothesis was formulated as "there is a difference between the levels of the support of stakeholders that are informed about the BMF".

Consequently, the K Independent Samples Test (Kruskal Wallis Test) was conducted among nonparametric tests for the purpose of identifying the differences in views according to the stakeholder groups.

Afterwards, the levels of support of the stakeholders were explained upon utilizing crosstabs for the purpose of investigating in detail the responses provided for the questions raised in the first group of questions. These tables provided significant contribution in revealing the levels of support by stakeholders to the BMF.

\section{Results}

3.1. Willingness and Preferences of Stakeholders According to Their Level of Knowledge about the Model Forest Concept

The key research question was to investigate whether the level of stakeholders' support for the Bucak MF was linked to if they were or were not previously informed about the Model Forest concept. Therefore, as the data did not have a normal distribution, the Mann-Whitney U test was used in the nonparametric Independent Samples T-test. The values obtained from this test are presented in Table 2. 
Table 2. Results of the Mann-Whitney U Test conducted according to being or not being informed about the Bucak Model Forest \#.

\begin{tabular}{|c|c|c|c|c|c|}
\hline $\begin{array}{l}\text { The number of } \\
\text { the question in } \\
\text { questionnaire }\end{array}$ & Willingness and preferences & $\begin{array}{c}\text { Mann- } \\
\text { Whitney U }\end{array}$ & $\begin{array}{l}\text { Wilcoxon } \\
\text { W }\end{array}$ & $\mathbf{Z}$ & $\begin{array}{l}\text { Asymp. } \\
\text { Sig. } \\
\text { (2-tailed) }\end{array}$ \\
\hline 2 & $\begin{array}{l}\text { Willingness to contribute to the } \\
\text { BMF development }{ }^{a}\end{array}$ & 315 & 370 & -0.930 & 0.352 \\
\hline 3 & $\begin{array}{l}\text { Willingness to be involved in the } \\
\text { activities a }^{\text {a }}\end{array}$ & 325 & 380 & -1.105 & 0.269 \\
\hline 4 & $\begin{array}{l}\text { Willingness to provide advisory } \\
\text { support }^{\text {a }}\end{array}$ & 335 & 282 & -0.663 & 0.507 \\
\hline 5 & $\begin{array}{l}\text { Willingness to provide financial } \\
\text { support }^{\text {a }}\end{array}$ & 320 & 375 & -0.520 & 0.603 \\
\hline 6 & $\begin{array}{l}\text { Willingness to be involved in the } \\
\text { projects conducted for the benefit } \\
\text { of the society }{ }^{b}\end{array}$ & 297 & 352 & -0.970 & 0.332 \\
\hline 7 & $\begin{array}{l}\text { Willingness to contribute to } \\
\text { transfer natural heritage to future } \\
\text { generations }^{b}\end{array}$ & 216 & 271 & -2.370 & $0.018 *$ \\
\hline 8 & $\begin{array}{l}\text { Contribution to the generation of } \\
\text { a conscious and environmentalist } \\
\text { society }{ }^{b}\end{array}$ & 302 & 357 & -0.866 & 0.386 \\
\hline 9 & $\begin{array}{l}\text { Contribution to the preservation of } \\
\text { the natural wealth of the region }{ }^{b}\end{array}$ & 264 & 319 & -1.746 & 0.081 \\
\hline 10 & $\begin{array}{l}\text { Willingness to contribute to the } \\
\text { planning of nature conservation } \\
\text { activities }{ }^{b}\end{array}$ & 344.5 & 399.5 & -0.103 & 0.918 \\
\hline 11 & $\begin{array}{l}\text { Provision of financial support to } \\
\text { the implementation of nature } \\
\text { conservation activities }{ }^{b}\end{array}$ & 306 & 361 & -0.661 & 0.508 \\
\hline 12 & $\begin{array}{l}\text { Support for the development of } \\
\text { the inhabitants of the region }{ }^{b}\end{array}$ & 272 & 327 & -1.478 & 0.139 \\
\hline 13 & $\begin{array}{l}\text { Willingness to create a forest that } \\
\text { stores carbon for fulfilling our } \\
\text { responsibility towards nature }^{b}\end{array}$ & 231.5 & 286.5 & -2.476 & $0.013 *$ \\
\hline 14 & $\begin{array}{l}\text { Support for the elimination of } \\
\text { factors endangering forests }{ }^{b}\end{array}$ & 266.5 & 321.5 & -1.748 & 0.080 \\
\hline 15 & $\begin{array}{l}\text { Support for trainings related with } \\
\text { forestry activities }{ }^{b}\end{array}$ & 311.5 & 366.5 & -0.665 & 0.506 \\
\hline 16 & $\begin{array}{l}\text { Ensuring cooperation with the } \\
\text { Forest Administration }{ }^{b}\end{array}$ & 276.5 & 331.5 & -1.472 & 0.141 \\
\hline
\end{tabular}

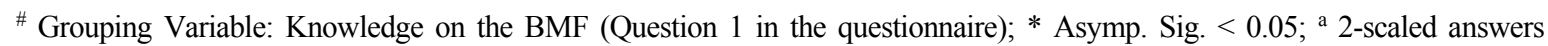
comprising Yes or No; ${ }^{b}$ Five-scale answers comprising, $1=$ strongly disagree to $5=$ strongly agree.
}

According to these results, the $\mathrm{H}_{\mathrm{A}}$ hypothesis, i.e., that there is a difference between stakeholders being informed about the BMF and the extent to which they are willing to support the BMF, was accepted 
only for one of the variables (Table 2). This variable was "Willingness to create a forest that stores carbon for fulfilling our responsibility towards nature".

\subsection{Stakeholder Groups' Willingness of Being Involved in the Bucak Model Forest Development}

The analysis of the data shows that willingness of being involved in the Model Forest development was much higher among those stakeholders that were informed then among those that were not informed about the Model Forest concept in general and the BMF particularly (Table 3).

Results of the Kruskal Wallis test to identify the differences of the stakeholders' willingness in BMF development was shown in Table 3.

Table 3. Willingness of being involved in the Bucak Model Forest development.

\begin{tabular}{lccccc}
\hline Willingness & Mean & Std. Deviation & Chi-Square & df & $\begin{array}{c}\text { Asymp. Sig. } \\
\text { (2-tailed) }\end{array}$ \\
\hline Knowledge on the BMF & 1.8750 & 0.33281 & 12.884 & 4 & $0.012 *$ \\
\hline $\begin{array}{l}\text { Willingness to be involved in the } \\
\text { activities conducted for the BMF }\end{array}$ & 1.9625 & 0.19118 & 11.406 & 4 & $0.022 *$ \\
\hline
\end{tabular}

* Asymp. Sig. $<0.05$.

According to these results, it may be observed from Table 3 that there is a difference between stakeholders in terms of their knowledge of the Model Forest concept and mission.

The willingness to be involved in the activities aimed at developing the BMF varied among different groups of stakeholders (Table 4). Approximately $87.5 \%$ of stakeholders declared to be informed about the mission and the purpose of BMF. However, the majority (50\%) of informed stakeholders were from the public sector. Only $7.5 \%$ and $2.5 \%$ of the informed stakeholders were from the civil and private sectors, respectively. Overall, $89 \%$ of the stakeholders that represented all sectors were willing to contribute and to provide support to the projects aimed at developing the BMF.

FPEs and LGUs were the most willing stakeholders groups to be involved with the development of BMF. NGOs and VCs were the less willing groups with a rate of $11 \%$, respectively, to BMF. The same stakeholders were also willing to take part in the activities aimed at developing the BMF.

Table 4. Willingness to contribute to Bucak Model Forest by stakeholders from different sectors.

\begin{tabular}{clcccccc}
\hline \multirow{2}{*}{ Willingness } & \multicolumn{2}{c}{ Civil } & \multicolumn{2}{c}{ Private } & \multicolumn{2}{c}{ Public } & Total \\
\cline { 2 - 6 } Yes & NGOs & POs & FPEs & LGUs & VCs \\
\hline \multirow{2}{*}{ group } & $77 \%$ & $93 \%$ & $100 \%$ & $100 \%$ & $77 \%$ & $89 \%$ \\
\hline \multirow{2}{*}{ No } & $\begin{array}{l}\text { Percentage within } \\
\text { group }\end{array}$ & $23 \%$ & $7 \%$ & $0 \%$ & $0 \%$ & $23 \%$ & $11 \%$ \\
\hline & $\mathrm{N}$ & 17 & 14 & 9 & 23 & 17 & 80 \\
\hline
\end{tabular}

Regarding the willingness to provide advisory support for the development of BMF our results show that stakeholders in all groups were generally willing ( $>88 \%$, and on average $96 \%)$ to support BMF development (Table 5). 
Table 5. The willingness to provide advisory support for the Bucak Model Forest.

\begin{tabular}{|c|c|c|c|c|c|c|c|}
\hline \multirow{2}{*}{ Willingness } & & \multicolumn{2}{|c|}{ Civil } & \multirow{2}{*}{$\begin{array}{l}\text { Private } \\
\text { FPEs }\end{array}$} & \multicolumn{2}{|c|}{ Public } & \multirow{2}{*}{ Total } \\
\hline & & NGOs & POs & & LGUs & VCs & \\
\hline Yes & $\begin{array}{l}\text { Percentage within } \\
\text { group }\end{array}$ & $88 \%$ & $100 \%$ & $100 \%$ & $100 \%$ & $94 \%$ & $96 \%$ \\
\hline No & $\begin{array}{l}\text { Percentage within } \\
\text { group }\end{array}$ & $12 \%$ & $0 \%$ & $0 \%$ & $0 \%$ & $6 \%$ & $4 \%$ \\
\hline & $\mathrm{N}$ & 17 & 14 & 9 & 23 & 17 & 80 \\
\hline
\end{tabular}

However, when it comes to providing a financial support, the studied stakeholders remained hesitant (Table 6). Nearly $88 \%$ of VCs and $71 \%$ of NGOs were unwilling to provide financial support to the BMF (Table 6). Thus only intellectual support may be obtained from them by the BMF. It may be observed that both intellectual support and financial support may be obtained from FPEs, LGUs and POs for the development of the BMF.

Table 6. The willingness of stakeholders to provide financial support for the Bucak Model Forest.

\begin{tabular}{cccccccc}
\hline \multirow{2}{*}{ Willingness } & \multicolumn{2}{c}{ Civil } & \multicolumn{2}{c}{ Private } & \multicolumn{2}{c}{ Public } & \multirow{2}{*}{ Total } \\
\cline { 3 - 6 } & NGOs & POs & FPEs & LGUs & VCs & \\
\hline \multirow{2}{*}{ Yes } & Percentage within group & $29 \%$ & $43 \%$ & $56 \%$ & $52 \%$ & $12 \%$ & $38 \%$ \\
\hline \multirow{2}{*}{ No } & Percentage within group & $71 \%$ & $57 \%$ & $44 \%$ & $48 \%$ & $88 \%$ & $62 \%$ \\
\hline \multicolumn{2}{c}{ N } & 17 & 14 & 9 & 23 & 17 & 80 \\
\hline
\end{tabular}

\subsection{Stakeholders' Preferences in the Future Activities of Bucak Model Forest Development}

Model Forest practices constitute a learning approach expressing a long-term process rather than a project. It is thus highly important to transfer the natural and cultural heritage to the future, create a conscious and environmentally aware society and develop communities in the countryside in the region. Very important roles are to be played by the stakeholders in the conduct of these future-oriented activities. A Kruskal Wallis test was performed for the purpose of identifying the differences in opinion of the stakeholders with regard to what activity they prefer in the efforts to be displayed for the development of BMF (Table 7).

Table 7. The stakeholders' preferences in the future activities of the Bucak Model Forest Development ${ }^{\#}$.

\begin{tabular}{lccccc}
\hline \multicolumn{1}{c}{ Preferences } & Mean & $\begin{array}{c}\text { Std. } \\
\text { Deviation }\end{array}$ & $\begin{array}{c}\text { Chi- } \\
\text { Square }\end{array}$ & df & $\begin{array}{c}\text { Asymp. Sig. } \\
\text { (2-tailed) }\end{array}$ \\
\hline $\begin{array}{l}\text { Provision of financial support to the implementation of } \\
\text { nature conservation activities }\end{array}$ & 2.8625 & 1.63617 & 18.054 & 4 & $0.001 *$ \\
$\begin{array}{l}\text { Support for the elimination of factors endangering forests } \\
\text { N }\end{array}$ & 4.7625 & 0.53353 & 12.103 & 4 & $0.017 *$ \\
\hline
\end{tabular}

${ }^{*}$ Grouping Variable: Stakeholders; * Asymp. Sig. $<0.05$. 
The Asymp. Sign. value revealed that the point where the stakeholders remained hesitant in providing support was the area of financial support. Similarly, the support level of the stakeholders towards eliminating the factors endangering the forests in the region was also found to be insufficient.

Table 8. The number out of 80 , and mean percentage, of stakeholders' preferences in the future activities of the Bucak Model Forest Development.

\begin{tabular}{|c|c|c|c|c|c|c|c|}
\hline & \multirow{2}{*}{$\begin{array}{c}\text { Level } \\
\text { of response * }\end{array}$} & \multicolumn{2}{|c|}{ Civil } & \multirow{2}{*}{$\begin{array}{l}\text { Private } \\
\text { FPEs }\end{array}$} & \multicolumn{2}{|c|}{ Public } & \multirow{2}{*}{$\begin{array}{c}\% \\
\text { Mean } \\
\text { Value }\end{array}$} \\
\hline & & NGOs & POs & & LGUs & VCs & \\
\hline \multirow{3}{*}{$\begin{array}{l}\text { Willingness to be involved in the projects } \\
\text { conducted for the benefit of the society }\end{array}$} & ++ & 13 & 10 & 6 & 15 & 13 & 71 \\
\hline & + & 3 & 4 & 2 & 8 & 4 & 26 \\
\hline & \pm & 1 & 0 & 1 & 0 & 0 & 3 \\
\hline \multirow{3}{*}{$\begin{array}{l}\text { Willingness to contribute to the transfer of natural } \\
\text { heritage to future generations }\end{array}$} & ++ & 8 & 9 & 9 & 16 & 12 & 68 \\
\hline & + & 5 & 3 & 0 & 7 & 5 & 25 \\
\hline & - & 4 & 2 & 0 & 0 & 0 & 8 \\
\hline \multirow{3}{*}{$\begin{array}{l}\text { Contribution to the generation of a conscious and } \\
\text { environmentalist society }\end{array}$} & ++ & 13 & 10 & 6 & 15 & 12 & 70 \\
\hline & + & 3 & 4 & 3 & 7 & 5 & 28 \\
\hline & \pm & 1 & 0 & 0 & 1 & 0 & 3 \\
\hline \multirow{3}{*}{$\begin{array}{l}\text { Contribution to the preservation of the natural } \\
\text { wealth of the region }\end{array}$} & ++ & 13 & 10 & 9 & 15 & 16 & 79 \\
\hline & + & 1 & 3 & 0 & 8 & 1 & 16. \\
\hline & - & 3 & 1 & 0 & 0 & 0 & 5 \\
\hline \multirow{3}{*}{$\begin{array}{l}\text { Provision of financial support to the } \\
\text { implementation of nature conservation activities }\end{array}$} & ++ & 11 & 9 & 9 & 14 & 15 & 73 \\
\hline & + & 3 & 5 & 0 & 9 & 2 & 24 \\
\hline & \pm & 3 & 0 & 0 & 0 & 0 & 4. \\
\hline \multirow{4}{*}{$\begin{array}{l}\text { Provision of financial support to the } \\
\text { implementation of nature conservation activities }\end{array}$} & ++ & 4 & 4 & 6 & 5 & 1 & 25 \\
\hline & + & 2 & 3 & 2 & 6 & 1 & 18 \\
\hline & \pm & 2 & 1 & 1 & 3 & 1 & 10 \\
\hline & - & 9 & 6 & 0 & 9 & 14 & 48 \\
\hline \multirow{3}{*}{$\begin{array}{l}\text { Ensuring cooperation with the Forest } \\
\text { Administration }\end{array}$} & ++ & 14 & 10 & 9 & 14 & 15 & 78 \\
\hline & + & 2 & 2 & 0 & 9 & 2 & 19 \\
\hline & \pm & 1 & 2 & 0 & 0 & 0 & 4 \\
\hline
\end{tabular}

* ++ Strongly agree, + Agree, \pm Neutral, - Disagree.

Regarding stakeholders' preferences to engage in the future BMF activities (Table 8), nearly $71 \%$ of the stakeholders stated that they would always be involved in projects aimed at providing benefits to the society, while $26 \%$ declared they may become involved in such projects. Generally, a significant majority would like to be involved in projects aimed at providing benefit to the society. The proportion of stakeholders which do not wish to contribute to the transfer of natural heritage to the future generations was $8 \%$. Nearly all of the stakeholder groups would like to contribute to the creation of a conscious and environmentalist society (98\%). About $95 \%$ of the stakeholders would like to contribute to the preservation of natural wealth. While $96 \%$ of the stakeholders wished to become involved in the planning of the activities on the preservation of nature, $58 \%$ indicated that they may provide financial support to the conduct of the activities on the nature conservation. The stakeholders wished to establish a carbon storing forest for fulfilling their responsibilities towards nature and provided a high support level also for the elimination of the factors endangering forests. Additionally, local people would like to be 
involved in training activities aimed at raising the level of knowledge. Nearly $96 \%$ of the stakeholders declared that they may cooperate with the forest administration.

The activities drawing most attention from the stakeholders and receiving the highest level of support in the development of BMF were the willingness to be involved in the training activities for the creation of an environmentally conscious society, and to contribute to the preservation of the natural resources in the region and their transfer to future generations.

\section{Discussion}

A Model Forest partnership represents a voluntary and neutral forum, which encourages all stakeholders to participate in the decisions impacting them. This study shows that to ensure stakeholder support it is necessary to explain the Model Forest concept to all stakeholders.

This study demonstrates that the BMF received support of stakeholders for developing the necessary partnership to be established for the management of the BMF. The findings show that there is a positive relation between stakeholders being informed about the BMF and their interest in providing support. Generally, SFM has a greater likelihood of succeeding if it includes the informed participation of all stakeholders [27]. It is thus important to consider the capacity of local organisations, not as an alternative but as an important complement to both central and local bureaucratic institutions [37].

The last two decades have witnessed a paradigm shift in conservation and natural resource management away from costly state-centred control towards approaches in which local stakeholders play a much more active role [38]. The stakeholders in Bucak participated in meetings about the Model Forest concept. These meetings created awareness among the stakeholders. They realized that the BMF aims at contributing to their environmental, social and economic conditions and they want to make use of innovative approaches. According to the Model Forest development guide [30], stakeholders generally join a Model Forest because they want to explore alternatives to existing natural resource management and innovative approaches.

It was observed that public and private sector stakeholders were most prone to cooperate voluntarily in order to achieve the development of BMF. While the stakeholders were generally ready to provide advisory support, their level of financial support was significantly lower. VCs and NGOs were unwilling to provide financial support to the BMF. However, the low level of financial support does not seem to be an obstacle for initiating the BMF initiative. Because $99 \%$ of the forests in Turkey are owned by the state and are managed and operated by the GDF, a major part of BMF's activities enters into the sphere of activities of this organisation. Therefore, governmental budget can be used for conduct of the relevant activities for the conservation and expansion of the BMF. However, also other stakeholders need financial support to climb the ladder of participation [39]. To enhance multi-level learning towards SFM at local, regional, national and international levels [40], additional funding to encourage collaboration is needed from, for example, the Governorship of Burdur, the Western Mediterranean Development Agency and European Union Funds. However, we emphasize that imported knowledge, experience and technology need to be adapted to local and regional conditions [28]. This calls for funding also for place-based transdisciplinary knowledge production and learning based on comparisons of different MF initiatives, such as Bergslagen MF in Sweden which the Swedish co-authors work with [40], as well as other Model Forest initiatives and concepts aiming at supporting sustainable forest and woodland landscapes [41]. 
It is thus essential that stakeholders work together to identify a common vision [30]. In the development of BMF, the stakeholders' high level of willingness to collaborate forms an important foundation towards the establishment of a representative governance structure and a broader community of stakeholders working together. Moreover, the Forestry administration in Turkey has a strong organization structure, and knowledge and experience about SFM [33] at the local and regional level. The successful development of a representative and inclusive partnership is a prerequisite for ecological, cultural, social and economic development of the BMF. By formally establishing the BMF, and collaborating with other MF initiatives, Turkey can have the chance to share its experiences and knowledge internationally.

\section{Conclusions}

The Model Forest concept aims at convening people and organizations with different interests and perspectives within the scope of developing an inclusive partnership [42]. This partnership focuses on achieving sustainable development in the forest landscapes by applying and demonstrating natural resource management practices that are environmentally sound, socially acceptable and economically viable. Involvement of the stakeholders is crucial to develop, test and share innovative solutions to the challenges of sustainable development as a societal process, and sustainability as tangible outcomes in forest landscapes. The willingness to participate and support partnership development towards sustainability in a landscape is the key factor in a MF initiative to develop novel and innovative approaches to implement SFM policy.

This study was carried out for the purpose of identifying the support level of the stakeholders located in the district of Bucak towards the BMF. We found a positive relationship between being informed about the MF concept, and stakeholders' willingness to providing support to the Bucak MF. We conclude that to enhance participation in Model Forest activities, it is important that stakeholders are informed about the Model Forest concept and its mission.

\section{Acknowledgments}

Authors thank Mustafa Değirmenci (Regional Forest Director of Isparta), Hayrullah Y1ldırım (Branch Director of Forest Management and Planning of Isparta), Mehmet Karabacak (Forest Supervisor of Bucak), and local organizations in Bucak Region for contributions and support to this study. Anonymous reviewers provided valuable comments.

\section{Author Contributions}

Ahmet Tolunay and Türkay Türkoğlu led the research activities and the data analysis. Marine Elbakidze and Per Angelstam contributed to the development of the conceptual framework. The article has been written with collaboration of all the authors. All authors have read and approved the final manuscript.

\section{Conflicts of Interest}

The authors declare no conflict of interest. 


\section{References}

1. Higman, S.; Bass, S.; Judd, N.; Mayers, J.; Nussbaum, R. The Sustainable Forestry Handbook; Earthscan Publications Ltd.: London, UK, 1999; pp. 1-289.

2. Kennedy, J.J.; Ward, T.J.; Glueck, P. Evolving forestry and rural development: Beliefs at midpoint and close of the 20th century. For. Policy Econ. 2001, 3, 81-95.

3. Tolunay, A.; Türkoğlu, T. Perspectives and attitudes of forest products industry companies on the chain of custody certification: A case study from Turkey. Sustainability 2014, 6, 857-871.

4. Cubbage, F.; Diaz, D.; Yapura, P.; Dube, F. Impacts of forest management certification in Argentina and Chile. For. Policy Econ. 2010, 12, 497-504.

5. Purnomo, H.; Mendoza, G.A.; Prabhu, R. Analysis of local perspectives on sustainable forest management: An Indonesian case study. J. Environ. Manag. 2005, 74, 111-126.

6. Waeber, P.O.; Nitschke, C.R.; Le Ferrec, A.; Harshaw, H.W.; Innes, J.L. Evaluating alternative forest management strategies for the Champagne and Aishihik Traditional Territory, southwest Yukon. J. Environ. Manag. 2013, 120, 148-156.

7. Kozak, R.A.; Spetic, W.C.; Harshaw, H.W.; Maness, T.C.; Sheppard, S.R.J. Public priorities for sustainable forest management in six forest dependent communities of British Columbia. Can. J. For. Res. 2008, 38, 3071-3084.

8. Nilsson, S. Experiences of policy reforms of the forest sector in transition and other countries. For. Policy Econ. 2005, 7, 831-847.

9. Lindenmayer, D.B.; Franklin, J.F. Conserving Forest Biodiversity: A Comprehensive Multiscale Approach; Island Press: Washington, DC, USA, 2002.

10. Kimmins, J.P. Forest Ecology: A Foundation for Sustainable Management, 2nd ed.; Prentice-Hall: Upper Saddle River, NJ, USA, 1997; pp. 1-596.

11. Elbakidze, M.; Angelstam, P. Implementing sustainable forest management in Ukraine's Carpathian Mountains: The role of traditional village systems. For. Ecol. Manag. 2007, 249, 28-38.

12. Status of tropical management report. International Tropic Timber Organization. Available online: http://www.itto.int/sfm/ (accessed on 23 February 2010).

13. McDonald, G.T.; Lane, M.B. Converging global indicators for sustainable forest management. For. Policy Econ. 2004, 6, 63-70.

14. Ministerial Conference on the Protection of Forests in Europe (MCPFE). In Proceedings of the Fourth Ministerial Conference on the Protection of Forests in Europe, Vienna, Austria, 28-30 April 2003.

15. Criteria and indicators for the conservation and sustainable management of temperate and boreal forests. Available online: http://www.rinya.maff.go.jp/mpci/ (accessed on 11 March 2010).

16. Hunt, L.; Haider, W. Fair and effective decision making processes in forest management planning. Soc. Nat. Resour. 2001, 14, 873-887.

17. Wallace, M.G.; Cortner, H.J.; Moote, M.A. Moving Toward Ecosystem Management: Examining a Change in Philosophy for Resource Management. Ecology 1996, 3, 1-36.

18. Varma, V.K.; Ferguson, I.; Wild, I. Decision support system for the sustainable forest management. For. Ecol. Manag. 2000, 128, 49-55. 
19. Blicharska, M.; Angelstam, P.; Elbakidze, M.; Axelsson,R.; Skorupski, M.; Węgiel, A. The Polish Promotional Forest Complexes: Objectives, implementation and outcomes towards sustainable forest management? For. Policy Econ. 2012, 23, 28-39.

20. Axelsson, R.; Angelstam, P.; Elbakidze, M.; Stryamets, N.; Johansson, K.E. Sustainable development and sustainability: Landscape approach as a practical interpretation of principles and implementation concepts. J. Landsc. Ecol. 2011, 4, 5-30.

21. Hall, J.E. Canada's Model Forest Program-Bringing community forest values into the development of sustainable forest management in the Canadian context. Available online: http://www.odi.org/sites/odi.org.uk/files/odi-assets/publications-opinion-files/1142.pdf (accessed on 11 April 2014).

22. The International Model Forest Network. A Global Approach to Ecosystem Sustainability. Available online: http://www.imfn.net/userfiles/IMFN_Book_Eng_web.pdf (accessed on 13 May 2014).

23. Besseau, P.; Dansou, K.; Johnson, F. The International Model Forest Network (IMFN): Elements of Success. For. Chron. 2002, 78, 648-654.

24. LaPierre, L. Canada's Model Forest Program. For. Chron. 2002, 78, 613-617.

25. Elbakidze, M.; Angelstam, P.K.; Axelsson, R. Multi-stakeholder collaboration in Russian and Swedish Model Forest Initiatives: Adaptive governance toward sustainable forest management. Ecol. Soc. 2012, 15, Article 14.

26. Sinclair, A.J.; Smith, D.L. Policy Review The Model Forest Program in Canada: Building Consensus on Sustainable Forest Management? Soc. Natur. Resour. 1999, 12, 121-138.

27. Chouinard, O.; Perron, J. Learning about community capacity in the Fundy Model Forest. For. Chron. 2002, 78, 637-642.

28. Elbakidze, M.; Angelstam, P.; Axelsson, R. Stakeholder identification and analysis for adaptive governance in the Kovdozersky Model Forest, Russian Federation. For. Chron. 2012, 88, 298-305.

29. The International Model Forest Network. Model Forests. Available online: http://www.imfn.net/ model-forests (accessed on 20 May 2014).

30. Model Forest Development Guide 2008. Available online: http:/www.imfn.net/system/files/ Model_Forest_Development_Guide_en.pdf (accessed on 1 May 2014).

31. Yalova Model Forest. Available online: http://yalovamodelormani.org.tr/ (accessed on 10 March 2014).

32. Türkoğlu, T. The Timber Supplement to Forestry Industry in Respect to Sustainable Forest Management and Certification of Forest Products in Turkey. Ph.D. Thesis, Süleyman Demirel University, Isparta, Turkey, July 2011.

33. Sustainable Forest Management Criteria and Indicators Report, 2008. Available online: http://web.ogm.gov.tr/birimler/merkez/StratejiGelistirme/Dokumanlar/soy (accessed on 12 November 2009).

34. Ministry of Environment and Forestry. 2004-2023 National Forest Program of Turkey; Ministry of Environment and Forestry: Ankara, Turkey, 2004; pp. 1-95.

35. Turkish Statistical Institute. The Results of Address Based Population Registration System, Ankara, Turkey, 2013. Available online: http://www.tuik.gov.tr (accessed on 15 June 2014).

36. Kingsley, G.T.; Gibson, J.O. Civil Society, the Public Sector, and Poor Communities. Available online: http://www.urban.org/UploadedPDF/pub_12.pdf (accessed on 15 May 2014). 
37. Boudo, H.N.; Savadogo, P.; Tiveau, D.; Ouedraogo, B. State, Forest and Community: Challenges of Democratically Decentralizing Forest Management in the Centre-West Region of Burkina Faso. Sustain. Dev. 2009, 19, 275-288.

38. Shackleton, S.; Campbell, B.; Wollenberg, E.; Edmunds, D. Devolution and community-based natural resource management: Creating space for local people to participate and benefit? ODI Nat. Resour. Perspect. 2002, 76, 1-6.

39. Arnstein, S.R. A Ladder of Citizen Participation. JAIP 1969, 35, 216-224.

40. Axelsson, R.; Angelstam, P.; Myhrman, L.; Sädbom, S.; Ivarsson, M.; Elbakidze, M.; Andersson, K.; Cupa, P.; Diry, C.; Doyon, F.; et al. Evaluation of multi-level social learning for sustainable landscapes: Perspective of a development initiative in Bergslagen, Sweden. AMBIO 2013, 42, 241-253.

41. Angelstam, P.; Elbakidze, M.; Axelsson, R. Knowledge production and learning for sustainable landscapes: Europe's East and West as a laboratory. AMBIO 2013, 43, 113-265.

42. Elbakidze, M.; Angelstam, P.; Axelsson, R. Sustainable forest management as an approach to regional development in the Russian Federation: State and trends in Kovdozersky Model Forest in the Barents region. Scand. J. For. Res. 2007, 22, 568-581.

(C) 2014 by the authors; licensee MDPI, Basel, Switzerland. This article is an open access article distributed under the terms and conditions of the Creative Commons Attribution license (http://creativecommons.org/licenses/by/4.0/). 